\title{
Evidence of differing genotypic effects of PPAR $\alpha$ in women and men
}

\author{
Q H Khan, D E Pontefract, S lyengar, S Ye
}

J Med Genet 2004;41:e79 (http://www.jmedgenet.com/cgi/content/full/41/6/e79). doi: 10.1136/jmg.2003.014407

$P$ eroxisome proliferator activated receptor alpha (PPAR $\alpha)$, ligand inducible transcription factor of the nuclear receptor family, plays an important part in the regulation of many genes involved in lipid metabolism and atherogenesis. ${ }^{1-3}$ This nuclear receptor is the cellular target of the fibrate drugs, which can lower triglyceride levels and reduce risk of acute coronary ischaemic events. ${ }^{45}$ Gender specific differences in PPAR $\alpha$ expression and in response to PPAR $\alpha$ deficiency have been observed in many animal studies. ${ }^{6-12}$

There is emerging evidence suggesting that, in humans, variation in the gene encoding PPAR $\alpha$ contributes to interindividual variability in lipid levels, ${ }^{13}{ }^{14}$ body weight, ${ }^{15} 16$ and risk of coronary ischaemic events. ${ }^{17}$ In this study, we examined the PPAR $\alpha$ gene Leul62Val and intron $7 \mathrm{G}>\mathrm{C}$ polymorphisms $^{17-19}$ in a large cohort of Caucasian patients with coronary artery disease, and found that the genotypic effects of PPAR $\alpha$ on plasma triglyceride level, hypertension prevalence, and myocardial infarction differed between men and women.

\section{SUBJECTS AND METHODS Subjects}

The subjects in this study were participants in the Southampton atherosclerosis study, all having atherosclerosis in at least one coronary artery, as described previously. ${ }^{20} 21$ The demographic and clinical characteristics of the subjects are summarised in table 1. Data on fasting levels of triglycerides, total cholesterol, and HDL cholesterol were available for 1017, 1110, and 630 subjects, respectively, measured in the clinical chemistry department of the Southampton General Hospital using standard quality controlled enzymatic methods. A total of 649 patients were receiving statin treatment and 16 were receiving fibrate (PPAR $\alpha$ agonist) treatment. The study was approved by the local research ethics committee, and all subjects gave written consent. A $10 \mathrm{ml}$ blood sample was taken from each participant, and DNA was extracted using a salt precipitation method.

\section{Determination of genotypes}

Genotypes for the Leul62Val and intron 7 (G>C) polymorphisms were determined using previously described methods ${ }^{17}{ }^{18}$ with modifications. In brief, PCR reactions were carried out in a total volume of $20 \mu \mathrm{l}$, containing $20 \mathrm{mM}$ Tris$\mathrm{Cl}(\mathrm{pH}$ 8.4); $50 \mathrm{mM} \mathrm{KCl}, 0.05 \%(\mathrm{v} / \mathrm{v}) \mathrm{Wl} ; 2.5 \mathrm{mM}$ (for Leul62Val) or $2 \mathrm{mM}$ (for Intron $7 \mathrm{G}>\mathrm{C}$ ) $\mathrm{MgCl}_{2} ; 0.2 \mathrm{mM}$ each dNTP (dATP, dCTP, dGTP, and dTTP); 5 pmol forward primers; 5 pmol reverse primers; 1 unit Taq polymerase; and $21 \mathrm{ng}$ of genomic template DNA. The solution was overlaid with $20 \mu \mathrm{l}$ of paraffin and subjected to $95^{\circ} \mathrm{C}$ for three minutes; and to 35 cycles of: one minute of denaturation at $95^{\circ} \mathrm{C}$, one minute annealing at $72^{\circ} \mathrm{C}$ (decreasing by $1{ }^{\circ} \mathrm{C}$ per cycle to $59^{\circ} \mathrm{C}$ and at $59^{\circ} \mathrm{C}$ for the remaining cycles for Leul62Val, and decreasing by $1{ }^{\circ} \mathrm{C}$ per cycle to $54^{\circ} \mathrm{C}$ and at $54^{\circ} \mathrm{C}$ for the remaining cycles for intron $7 \mathrm{G}>\mathrm{C}$ ), and

\section{Key points}

- Peroxisome proliferators activated receptor alpha (PPAR $\alpha$ ) regulates the expression of genes involved in lipid metabolism, and the pathogenesis of atherosclerosis.

- The Leu162Val and intron $7 \mathrm{G}>\mathrm{C}$ polymorphisms in the PPAR $\alpha$ gene were analysed in a cohort $(899$ men and 279 women) of Caucasian patients with coronary artery disease.

- There was a significant gender-genotype interaction in relation to plasma levels of triglyceride in the women.

- In the men, there was an interaction between statin treatment and the Leu $162 \mathrm{Val}$ polymorphism.

- Hypertension was significantly less prevalent in female162Val allele carriers than in female noncarriers.

- Myocardial infarction was significantly more prevalent in female patients carrying the $\mathrm{C}$ allele of the intron 7 polymorphism than in female non-carriers.

- These results provide evidence of gender dependent effects of PPAR $\alpha$ genotypes on triglyceride levels and cardiovascular events.

one minute of extension at $72^{\circ} \mathrm{C}$. For the Leul62Val polymorphism, the forward and reverse primers were 5'GACTCAAGCTGGTGTATGACAAGT and 5'CGTTGTGTGAC ATCCCGACAGAAT, respectively, and the PCR products were incubated with the restriction enzyme Hinfl (recognition site 5'GANTC3') which cleaved the amplicon (117 bp) from the 162Val allele into two fragments, $93 \mathrm{bp}$ and $24 \mathrm{bp}$ in length. ${ }^{18}$ For the intron $7 \mathrm{G}>\mathrm{C}$ polymorphism, the forward and reverse primers were 5'ACAATCACTCCTTAAATATGG and 5'AAGT AGGGACAGACAGGACCAGTA, respectively, and the PCR products were incubated with the restriction enzyme Taq 1 (recognition site 5'TCGA3') which cleaved the amplicon (266 bp) from the $\mathrm{C}$ allele into two fragments, $216 \mathrm{bp}$ and $50 \mathrm{bp}$ in length. ${ }^{17}$ The products of digestion were then separated using gel electrophoresis, and detected by Vistra Green staining.

\section{Statistical analysis}

The HWE programme (ftp://linkage.rockefeller.edu/software/ utilities) was employed to assess whether the genotype distribution of the polymorphisms was in Hardy-Weinberg equilibrium; $t$ tests and $\chi_{2}$ tests, respectively, examined differences in continuous and categorical variables between genotype groups. The distribution of triglyceride levels was found to be skewed, and therefore log transformed triglyceride values were used in the analyses. Interactions between genotype and other variables were tested using a univariate 
general linear model if the dependent variable was continuous, or logistic regression analysis if the dependent variable was categorical. Odds ratios were calculated using logistic regression analysis. Linkage disequilibrium between the polymorphisms and the association metric D were analysed with the use of the ASSOCIATE program (ftp://linkage.rockefeller.edu/software/utilities). Haplotype frequencies were estimated using the Haplotyper program which employs a Bayesian algorithm. ${ }^{22}$ Stepwise linear regression analysis and stepwise logistic regression analysis with all genotypes and haplotypes, input as independent variables, were performed to investigate which polymorphism(s) and/or haplotype(s) accounted for the association of continuous and categorical variables with the PPAR $\alpha$ gene.

\section{RESULTS}

A total of 1108 subjects was successfully genotyped for the Leu 162Val polymorphism, and 1088 subjects were genotyped for the intron $7 \mathrm{G}>\mathrm{C}$ polymorphism. The frequencies of the $\mathrm{Leu} / \mathrm{Leu}, \mathrm{Leu} / \mathrm{Val}$, and $\mathrm{Val} / \mathrm{Val}$ genotypes were $84.1 \%$ ( $\mathrm{n}=$ 991), 9.6\% $(\mathrm{n}=113)$, and $0.3 \%(\mathrm{n}=4)$, respectively, and those for the $\mathrm{G} / \mathrm{G}, \mathrm{G} / \mathrm{C}$, and $\mathrm{C} / \mathrm{C}$ genotypes were $63.7 \%(\mathrm{n}=$ $750), 25.9 \%(\mathrm{n}=305)$, and $2.8 \%(\mathrm{n}=33)$, respectively. These genotype distributions were in concordance with Hardy-Weinberg equilibrium. The 162Val allele had a frequency of 0.055 (95\% CI from 0.046 to 0.065 ) and the C allele had a frequency of 0.170 (95\% CI from 0.155 to 0.187 ), both similar to those reported in other Caucasian samples. $^{131719}$ Mean age, gender ratio, smoking status, and family history of coronary artery disease did not significantly differ between genotype groups (tables 2 and 3 ). The percentages of patients on fibrate treatment were higher among the women than the men $(p=0.011$, table 1$)$. Since fibrate treatment might influence the genotypic effects of PPAR $\alpha$, the 16 patients (eight men and eight women) receiving fibrate treatment were excluded in all following analyses. The percentages of patients receiving statin treatment were similar among men and women $(p=0.104$, table 1).

\section{Genetic effects of PPARa on plasma lipid levels}

A univariate analysis of variance using a general linear model revealed an interaction between gender and the Leul62Val polymorphism in relation to plasma triglyceride levels $(\mathrm{p}=$ 0.001 ). Analyses of the genotypic effect in male patients and female patients separately showed that, among the women, $162 \mathrm{Val}$ carriers had 30\% lower mean triglyceride levels than non-carriers ( $\mathrm{p}=0.007$, table 2$)$ whereas, among the men, there was no significant difference in triglyceride level between the genotype groups (table 2).

In men but not in women, there was an interaction between statin treatment and the Leul62Val polymorphism in relation to triglyceride levels $(\mathrm{p}=0.022$ in male patients and $\mathrm{p}=0.122$ in female patients). Among men who were not receiving statin treatment, the $162 \mathrm{Val}$ carriers had a $26 \%$ higher mean triglyceride level than the non-carriers (1.85 \pm $1.13 \mathrm{mmol} / \mathrm{l}$ in carriers, and $2.33 \pm 1.30 \mathrm{mmol} / \mathrm{l}$ in noncarriers; $p=0.027$ ) (fig 1); whereas among men treated with statins, the 162Val carriers had a $13 \%$ lower mean triglyceride level than the non-carriers $(1.97 \pm 1.15 \mathrm{mmol} / \mathrm{l}$ in carriers, and $1.72 \pm 1.27 \mathrm{mmol} / \mathrm{l}$ in non-carriers; $\mathrm{p}=$ 0.021 ) (fig 1). Among the women, in contrast, triglyceride levels were about $30 \%$ lower in 162 Val carriers than in noncarriers, regardless of whether or not they were receiving statin treatment (fig l).

Among the women, there was a non-significant trend towards lower total cholesterol levels and higher HDL levels in 162Val allele carriers (table 2). Among the men, the levels were similar in different Leu 162Val genotype groups. In both
Table 1 Characteristics of subjects

\begin{tabular}{|c|c|c|c|c|}
\hline Characteristic & $\begin{array}{l}\text { All } \\
(n=1178)\end{array}$ & $\begin{array}{l}\text { Men } \\
(n=899)\end{array}$ & $\begin{array}{l}\text { Women } \\
(n=279)\end{array}$ & Comparison* \\
\hline Age (years) & $63.3(10.0)$ & $62.5(10.1)$ & $65.7(9.2)$ & $p<0.001$ \\
\hline $\begin{array}{l}\text { Current/ } \\
\text { former } \\
\text { smokers }\end{array}$ & $\begin{array}{l}74.6 \% \\
(874)\end{array}$ & $\begin{array}{l}81.0 \% \\
(725)\end{array}$ & $\begin{array}{l}54.0 \% \\
(149)\end{array}$ & $p<0.001$ \\
\hline $\begin{array}{l}\text { Body mass } \\
\text { index }\left(\mathrm{kg} / \mathrm{m}^{2}\right)\end{array}$ & $\begin{array}{l}27.5 \\
(4.2)\end{array}$ & $\begin{array}{l}27.5 \\
(3.7)\end{array}$ & $\begin{array}{l}27.5 \\
(5.0)\end{array}$ & $p=0.925$ \\
\hline $\begin{array}{l}\text { Triglyceride } \\
(\mathrm{mmol} / \mathrm{l})\end{array}$ & $\begin{array}{r}1.86 \\
(1.22)\end{array}$ & $\begin{array}{r}1.92 \\
(1.17)\end{array}$ & $\begin{array}{r}1.68 \\
(1.34)\end{array}$ & $p=0.008$ \\
\hline $\begin{array}{l}\text { Cholesterol } \\
(\mathrm{mmol} / \mathrm{l})\end{array}$ & $\begin{array}{r}5.11 \\
(1.02)\end{array}$ & $\begin{array}{r}5.05 \\
(0.97)\end{array}$ & $\begin{array}{r}5.31 \\
(1.14)\end{array}$ & $p<0.001$ \\
\hline $\begin{array}{l}\mathrm{HDL} \\
\text { cholesterol } \\
\text { (mmol/l) }\end{array}$ & $\begin{array}{r}1.28 \\
(0.46)\end{array}$ & $\begin{array}{r}1.24 \\
(0.47)\end{array}$ & $\begin{array}{r}1.45 \\
(0.36)\end{array}$ & $p<0.001$ \\
\hline $\begin{array}{l}\text { Statin } \\
\text { treatment }\end{array}$ & $\begin{array}{l}55.9 \% \\
(649)\end{array}$ & $\begin{array}{l}54.5 \% \\
(486)\end{array}$ & $\begin{array}{l}60.1 \% \\
(163)\end{array}$ & $p=0.104$ \\
\hline $\begin{array}{l}\text { Fibrate } \\
\text { treatment }\end{array}$ & 16 (3.0\%) & 8 (1.9\%) & $\begin{array}{c}8 \\
(6.9 \%)\end{array}$ & $p=0.011$ \\
\hline Hypertension & $45 \%(530)$ & $42.3 \%$ (899) & $53.8 \%(150)$ & $P=0.001$ \\
\hline $\begin{array}{l}\text { Diabetes } \\
\text { mellitus }\end{array}$ & $\begin{array}{l}13.3 \% \\
(156)\end{array}$ & $\begin{array}{l}12.3 \% \\
(110)\end{array}$ & $\begin{array}{l}16.6 \% \\
(46)\end{array}$ & $p=0.064$ \\
\hline $\begin{array}{l}\text { Myocardial } \\
\text { infarction }\end{array}$ & $\begin{array}{l}48.4 \% \\
(504)\end{array}$ & $\begin{array}{l}51.2 \% \\
(412)\end{array}$ & $\begin{array}{l}38.7 \% \\
(92)\end{array}$ & $p=0.001$ \\
\hline $\begin{array}{l}\text { Family history } \\
\text { of } C A D\end{array}$ & $\begin{array}{l}48.5 \% \\
(571)\end{array}$ & $\begin{array}{r}46.8 \% \\
(421)\end{array}$ & $\begin{array}{l}53.8 \% \\
(150)\end{array}$ & $p=0.043$ \\
\hline
\end{tabular}

Data shown are mean (SD) for continuous variables and percentage (n) for categorical variables.

*Comparison between male and female patients. $n$, number; CAD, coronary artery disease.

men and women, no significant interaction between statin treatment and Leul62Val genotype on total cholesterol or HDL levels was detected, nor was there an association between the intron $7 \mathrm{G}>\mathrm{C}$ polymorphism and triglyceride, total cholesterol, or HDL-cholesterol levels (table 2).

\section{PPAR $\alpha$ genotypes in relation to hypertension, diabetes, and body mass index}

Among the female subjects, the prevalence of hypertension was significantly lower in $162 \mathrm{Val}$ carriers than in non-carriers $(p=0.007$, table 3$)$. Among the male subjects, hypertension was slightly less prevalent in 162Val carriers than in noncarriers, but the difference was not statistically significant (table 3). There was no interaction between genotype and statin treatment in relation to hypertension, in men or women.

There was no significant association between the intron 7 $\mathrm{G}>\mathrm{C}$ polymorphism and prevalence of hypertension (table 3 ). Neither the Leu 162Val polymorphism nor the intron $7 \mathrm{G}>\mathrm{C}$ polymorphism was associated with body mass index or prevalence of diabetes mellitus (tables 2 and 3).

\section{PPARa genotypes in relation to severity of atherosclerosis and risk of myocardial infarction}

Among the women, the prevalence of myocardial infarction was higher in those carrying the $\mathrm{C}$ allele of the intron 7 polymorphism than in non-carriers $(\mathrm{p}=0.019$, table 3$)$. In addition, the frequencies of $\mathrm{C}$ allele carriers were highest among those who had a history of both myocardial infarction and unstable angina, intermediate among those who had either myocardial infarction or unstable angina, and lowest among those had neither of these phenotypes $(46.8 \%, 35.2 \%$, and $29.0 \%$ respectively, $\mathrm{p}=0.044)$. Among the men, myocardial infarction was slightly more prevalent in $\mathrm{C}$ allele carriers than in non-carriers, but the difference was not statistically significant (table 3 ).

For both genders, the genotypic effect on myocardial infarction was more pronounced among those who were not receiving statin treatment. Among untreated women, the 
Table 2 Continuous variables in different genotype groups according to gender

\begin{tabular}{|c|c|c|c|c|c|c|c|c|c|c|}
\hline \multirow[b]{2}{*}{ Variable } & \multicolumn{2}{|l|}{ Leu/Leu } & \multicolumn{2}{|c|}{ Leu/ $\mathrm{Val}+\mathrm{Val} / \mathrm{Val}$} & \multirow[b]{2}{*}{$\mathrm{p}$ Value } & \multicolumn{2}{|l|}{$\mathbf{G} / \mathbf{G}$} & \multicolumn{2}{|l|}{$G / C+C / C$} & \multirow[b]{2}{*}{ p Value } \\
\hline & Mean (SD) & $\mathbf{n}$ & Mean (SD) & $\mathbf{n}$ & & Mean (SD) & $\mathbf{n}$ & Mean (SD) & $\mathbf{n}$ & \\
\hline \multicolumn{11}{|l|}{ Women* } \\
\hline Triglyceride $(\mathrm{mmol} / \mathrm{l})$ & $1.68(0.87)$ & 199 & $1.18(0.40)$ & 22 & 0.007 & $1.61(0.84)$ & 140 & $1.67(0.89)$ & 75 & 0.799 \\
\hline Cholesterol (mmol//) & $5.37(1.16)$ & 215 & $5.07(1.21)$ & 24 & 0.242 & $5.34(1.11)$ & 151 & $5.39(1.27)$ & 82 & 0.799 \\
\hline $\mathrm{HDL}(\mathrm{mmol} / \mathrm{l})$ & $1.43(0.36)$ & 94 & $1.59(0.35)$ & 12 & 0.162 & $1.44(0.39)$ & 68 & $1.42(0.30)$ & 38 & 0.792 \\
\hline BMI $\left(\mathrm{kg} / \mathrm{m}^{2}\right)$ & $27.54(4.97)$ & 223 & $27.67(5.28)$ & 26 & 0.896 & $27.59(4.85)$ & 155 & $27.56(5.21)$ & 88 & 0.965 \\
\hline Age (years) & $65.89(8.95)$ & 225 & 62.94 (11.02) & 26 & 0.122 & $65.51(9.11)$ & 157 & $65.66(9.66)$ & 88 & 0.904 \\
\hline \multicolumn{11}{|l|}{ Men $^{*}$} \\
\hline Triglyceride $(\mathrm{mmol} / \mathrm{l})$ & $1.91(1.15)$ & 644 & 1.96 (1.31) & 77 & 0.770 & $1.89(1.15)$ & 496 & $1.98(1.15)$ & 216 & 0.224 \\
\hline Cholesterol (mmol//) & $5.07(0.97)$ & 697 & 5.00 (1.07) & 84 & 0.538 & $5.08(0.99)$ & 536 & $5.05(0.92)$ & 235 & 0.556 \\
\hline $\mathrm{HDL}(\mathrm{mmol} / \mathrm{l})$ & $1.24(0.49)$ & 434 & $1.24(0.26)$ & 45 & 0.988 & $1.26(0.54)$ & 327 & $1.19(0.26)$ & 139 & 0.129 \\
\hline BMI $\left(\mathrm{kg} / \mathrm{m}^{2}\right)$ & $27.52(3.89)$ & 740 & 27.39 (3.49) & 90 & 0.775 & $27.54(3.93)$ & 572 & $27.59(4.15)$ & 245 & 0.859 \\
\hline Age (years) & $62.77(9.99)$ & 752 & 61.70 (11.08) & 90 & 0.345 & $62.78(9.90)$ & 580 & $62.19(10.49)$ & 258 & 0.443 \\
\hline
\end{tabular}

*Eight men and eight women receiving fibrate treatment were excluded. Emboldened value is statistically significant. SD, standard deviation; $\mathrm{n}$, number; $\mathrm{HDL}$, high density cholesterol; BMI, body mass index.

odds ratio for myocardial infarction was 2.27 (95\% CI from 1.01 to 5.11 ) for C allele carriers compared with non-carriers, whereas among women receiving statin treatment, the odds ratio was 1.67 (95\% CI from 0.82 to 3.40$)$. Among untreated and treated men, the odds ratios were 1.56 (95\% CI from 0.99 to 2.48 ) and 0.86 (95\% CI from 0.57 to 1.28 ), respectively.

There was no significant difference in the number of coronary arteries with $>50 \%$ stenosis between genotype groups of the Leul62Val or intron $7 \mathrm{G}>\mathrm{C}$ polymorphism (table 3 ).

\section{Haplotype analysis}

The Leul62Val and intron $7 \mathrm{G}>\mathrm{C}$ polymorphisms were in strong linkage disequilibrium, with the $162 \mathrm{Val}$ allele being linked with the $\mathrm{C}$ allele $\left(\mathrm{D}=0.0248 ; \mathrm{p}<10^{-6}\right)$. The frequencies of the Leu-G, Leu-C, Val-G, and Val-C haplotypes were $0.776,0.160,0.028$, and 0.036 , respectively. Among the women, the mean triglyceride level was lower in carriers of the Val-C haplotype compared with non-carriers $(\mathrm{p}=0.033$, table 4 ). The other phenotypes studied did not significantly differ between carriers and non-carriers (tables 4 and 5). Stepwise regression analyses showed that none of the haplotypes had a more significant association with triglyceride level or hypertension than the 162Val allele, and that none of the haplotypes had a more significant association with myocardial infarction than the $\mathrm{C}$ allele of the intron 7 polymorphism.

\section{DISCUSSION}

The main finding of this study is that in persons with coronary artery disease and without fibrate or statin treatment, there is a gender dependent genotypic effect of PPAR $\alpha$ on triglyceride levels, such that the 162Val allele is associated with a lower triglyceride level in female patients but with a higher triglyceride level in male patients. Gender specific differences in PPAR $\alpha$ expression and in PPAR $\alpha$ genotypic effect on lipid metabolism have been demonstrated in a number of animal studies. ${ }^{6-12}$ For example-it has been shown that in rodents, PPAR $\alpha$ expression levels in the liver are higher in males than in females, and that inactivating the PPAR $\alpha$ gene results in an increased hepatic triglyceride secretion rate in females but does not affect this rate in males. ${ }^{78}$ It has also been shown that gonadectomy abolishes the differences in hepatic PPAR $\alpha$ expression level between male and female rats, suggesting an influence of sex hormones on PPAR $\alpha$ expression. ${ }^{8}$ The results of the present study provide evidence of a gender dependent genotypic effect of PPAR $\alpha$ in humans. To our knowledge, there has been no reported study of PPAR $\alpha$ gene polymorphisms in coronary heart disease patients with parallel analyses in men and women. A previous study of male patients with coronary heart disease who were not receiving lipid lowering agents showed that $162 \mathrm{Val}$ carriers had higher plasma triglyceride levels than non-carriers, ${ }^{23}$ which is consistent with the findings in the male patients in the present study. Several reported studies of PPAR $\alpha$ polymorphisms have been

Table 3 Categorical variables in different genotype groups according to gender

\begin{tabular}{|c|c|c|c|c|c|c|}
\hline Variable & Leu/Leu & Leu/Val + Val/Val & p Value & G/G & $\mathrm{G} / \mathrm{C}+\mathrm{C} / \mathrm{C}$ & p Value \\
\hline Women* & $n=225$ & $n=26$ & & $\mathrm{n}=157$ & $\mathrm{n}=88$ & \\
\hline Hypertension & $54.7 \%$ & $26.9 \%$ & 0.007 & $54.8 \%$ & $50.0 \%$ & 0.472 \\
\hline Diabetes & $13.8 \%$ & $19.2 \%$ & 0.459 & $14.2 \%$ & $17.0 \%$ & 0.552 \\
\hline Smoking & $53.8 \%$ & $50.0 \%$ & 0.954 & $50.6 \%$ & $56.8 \%$ & 0.336 \\
\hline Family CAD history & $53.8 \%$ & $46.2 \%$ & 0.461 & $54.8 \%$ & $51.1 \%$ & 0.584 \\
\hline Diseased vessels $(n) \dagger$ & $46.7 / 34.7 / 18.7 \%$ & $53.8 / 34.6 / 11.5 \%$ & 0.633 & $45.9 / 36.9 / 17.2 \%$ & $50.0 / 31.8 / 18.2 \%$ & 0.720 \\
\hline Unstable angina & $28.9 \%$ & $38.5 \%$ & 0.313 & $28.0 \%$ & $34.1 \%$ & 0.321 \\
\hline Myocardial infarction & $46.9 \%$ & $53.8 \%$ & 0.500 & $42.3 \%$ & $58.0 \%$ & 0.019 \\
\hline Men* & $n=752$ & $n=90$ & & $n=580$ & $n=248$ & \\
\hline Hypertension & $43.0 \%$ & $36.7 \%$ & 0.254 & $42.8 \%$ & $40.3 \%$ & 0.515 \\
\hline Diabetes & $12.4 \%$ & $9.0 \%$ & 0.352 & $11.4 \%$ & $14.2 \%$ & 0.269 \\
\hline Smokers & $81.3 \%$ & $76.1 \%$ & 0.242 & $81.2 \%$ & $79.7 \%$ & 0.617 \\
\hline Family CAD history & $46.8 \%$ & $51.1 \%$ & 0.440 & $54.8 \%$ & $51.1 \%$ & 0.584 \\
\hline Diseased vessels $(n) \dagger$ & $39.2 / 33.2 / 27.5 \%$ & $37.8 / 30.0 / 32.2 \%$ & 0.627 & $39.7 / 34.0 / 26.4 \%$ & $36.7 / 30.2 / 33.1 \%$ & 0.145 \\
\hline Unstable angina & $27.9 \%$ & $32.2 \%$ & 0.393 & $28.8 \%$ & $26.2 \%$ & 0.448 \\
\hline Myocardial infarction & $56.3 \%$ & $52.2 \%$ & 0.468 & $54.8 \%$ & $58.5 \%$ & 0.334 \\
\hline
\end{tabular}

*Eight men and eight women receiving fibrate treatment were excluded. + Percentages of patients with one, two, or three coronary arteries with $>50 \%$ stenosis Emboldened $p$ value is statistically significant. $n$, number; CAD, coronary artery disease. 


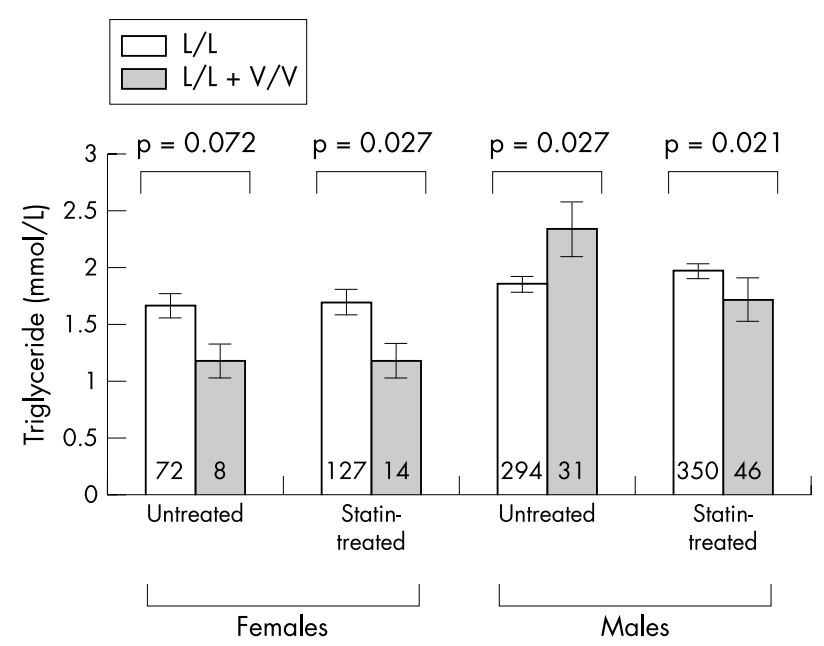

Figure 1 Plasma triglyceride levels in different genotype groups stratified by statin treatment. Patients (eight men and eight women) receiving fibrate treatment were excluded. Data shown are mean \pm standard error of mean.

conducted in healthy subjects, general population subjects, and diabetic patients. A study in healthy Japanese individuals showed that a PPAR $\alpha$ gene polymorphism-that is,Val227Ala, which is present in Japanese persons but not in Caucasians - is associated with triglyceride levels among women but not among men. ${ }^{24}$ However, a study of the Leul62Val polymorphism in a population sample of Caucasians did not show significant differences in triglyceride levels between the different genotype groups in men or women. ${ }^{13}$ Given that lipid levels are influenced by many genetic and environment factors, it is possible that the genotypic effects of PPAR $\alpha$ can vary, depending on the combinations of other factors.

Another key finding of this study was that in men with coronary heart disease, there was an interaction between PPAR $\alpha$ genotype and statin treatment on triglyceride levels. Thus, in the male patients who were not receiving lipid lowering treatment, triglyceride levels were higher in $162 \mathrm{Val}$ carriers than in non-carriers; however, among male patients receiving statin treatment, $162 \mathrm{Val}$ carriers had a lower mean triglyceride level than non-carriers (fig 1). This could be interpreted as a substantial triglyceride lowering effect of statins in male 162Val carriers but not in male non-carriers (fig 2). It has been shown that PPAR $\alpha$ agonists (fibrates)

Table 4 Continuous variables in carriers and noncarriers of the Val-C haplotype

\begin{tabular}{|c|c|c|c|c|c|}
\hline \multirow[b]{2}{*}{ Variable } & \multicolumn{2}{|l|}{ Non-carriers } & \multicolumn{2}{|l|}{ Carriers } & \multirow[b]{2}{*}{ p Value } \\
\hline & Mean (SD) & $\mathbf{n}$ & Mean (SD) & $\mathbf{n}$ & \\
\hline \multicolumn{6}{|l|}{ Women* } \\
\hline Triglyceride $(\mathrm{mmol} / \mathrm{l})$ & ) 1.71 (1.39) & 223 & $1.15(0.37)$ & 15 & 0.033 \\
\hline Cholesterol (mmol/l) & $5.32(1.15)$ & 241 & $5.21(1.34)$ & 16 & 0.713 \\
\hline $\mathrm{HDL}(\mathrm{mmol} / \mathrm{l})$ & $1.44(0.37)$ & 109 & $1.60(0.36)$ & 7 & 0.257 \\
\hline BMI $\left(\mathrm{kg} / \mathrm{m}^{2}\right)$ & $27.44(4.87)$ & 250 & $28.46(5.58)$ & 18 & 0.397 \\
\hline Age (years) & $65.75(8.95)$ & 253 & $63.17(12.22)$ & 18 & 0.253 \\
\hline \multicolumn{6}{|c|}{ Men* } \\
\hline Triglyceride (mmol/l) & ) 1.91 (1.15) & 709 & $1.92(1.24)$ & 56 & 0.754 \\
\hline Cholesterol (mmol/l) & $5.06(0.97)$ & 767 & $4.93(0.99)$ & 62 & 0.320 \\
\hline $\mathrm{HDL}(\mathrm{mmol} / \mathrm{l})$ & $1.24(0.48)$ & 471 & $1.23(0.26)$ & 35 & 0.867 \\
\hline $\mathrm{BMI}\left(\mathrm{kg} / \mathrm{m}^{2}\right)$ & $27.50(3.99)$ & 815 & $27.65(3.65)$ & 64 & 0.770 \\
\hline Age (years) & $62.75(10.02)$ & 827 & $60.54(10.80)$ & 64 & 0.091 \\
\hline
\end{tabular}

*Eight men and eight women receiving fibrate treatment were excluded. Emboldened $p$ value is statistically significant. SD, standard deviation; $n$, number; HDL, high density cholesterol; BMI, body mass index.

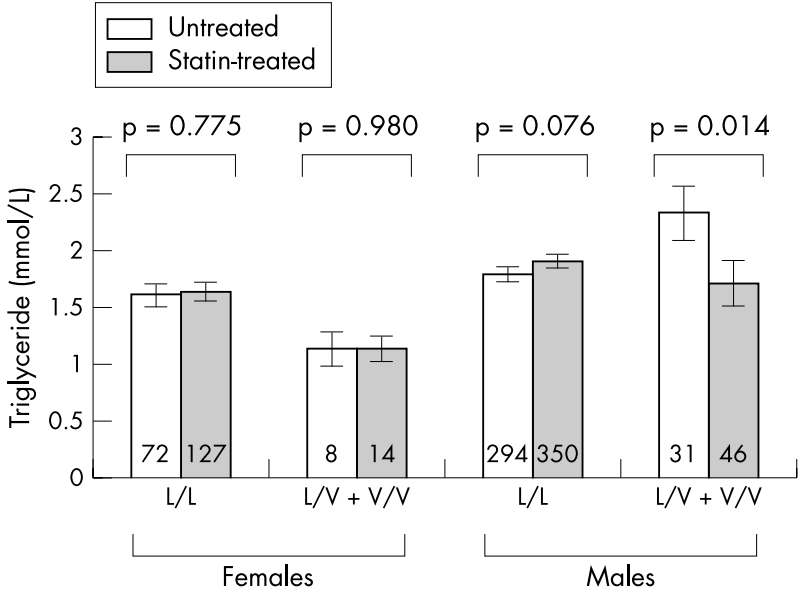

Figure 2 Plasma triglyceride levels in patients treated and untreated with statins stratified by genotypes. Eight women and eight men receiving fibrate treatment were excluded. Data shown are mean \pm standard error of mean.

have greater effects in lowering plasma triglyceride level and raising HDL cholesterol levels in 162Val carriers than in noncarriers. ${ }^{25} 26$ In our patient cohort, the number of subjects who were receiving PPAR $\alpha$ agonist treatment (eight women and eight men) was too small to analyse whether these drugs had different effects in different genotype groups. However, as described above, we found that in the male subjects there was an interaction between Leul62Val genotypes and statin (3-hydroxy-3-methylglutaryl coenzyme A reductase) treatment in determining plasma triglyceride levels. This genotype-statin interaction was not observed in the female subjects. The mechanism for the interaction between PPAR $\alpha$ genotype and statin treatment in the men is unclear. Laboratory experiments have shown that statins can increase the expression and activity of PPAR $\alpha$, and that some of the effects of statins on lipid levels might be mediated by a PPAR $\alpha$ dependent pathway. ${ }^{27-29}$ It is possible that clinically these effects are influenced by gender and PPAR $\alpha$ genotype.

At the blood vessel wall, PPAR $\alpha$ regulates the expression of a number of genes involved in the pathogenesis of atherosclerosis and ischaemic clinical events. ${ }^{30}$ Clinical trials have shown that fibrate drugs which are PPAR $\alpha$ agonists can

Table 5 Categorical variables in carriers and noncarries of the Val-C haplotype

\begin{tabular}{llll}
\hline Variable & Carriers & Non-carriers & p Value \\
\hline Women* & $n=253$ & $n=18$ & \\
Hypertension & $54.5 \%$ & $33.3 \%$ & 0.081 \\
Diabetes & $15.5 \%$ & $22.2 \%$ & 0.455 \\
Smokers & $54.4 \%$ & $50.0 \%$ & 0.717 \\
Family history of CAD & $53.8 \%$ & $44.4 \%$ & 0.444 \\
No. of diseased vessels† & $47.0 / 34.8 /$ & $55.6 / 33.3 /$ & 0.690 \\
& $18.2 \%$ & $11.1 \%$ & \\
Unstable angina & $28.9 \%$ & $44.4 \%$ & 0.163 \\
Myocardial infarction & $47.2 \%$ & $55.6 \%$ & 0.494 \\
Men* & & & \\
Hypertension & $42.3 \%$ & $37.5 \%$ & 0.451 \\
Diabetes & $12.1 \%$ & $11.1 \%$ & 0.812 \\
Smokers & $81.0 \%$ & $79.0 \%$ & 0.709 \\
Family history of CAD & $46.6 \%$ & $50.0 \%$ & 0.595 \\
No. of diseased vessels† & $39.3 / 33.1 /$ & $34.4 / 32.8 /$ & 0.620 \\
& $27.6 \%$ & $32.8 \%$ & \\
Unstable angina & $27.7 \%$ & $34.4 \%$ & 0.252 \\
Myocardial infarction & $56.1 \%$ & $56.3 \%$ & 0.982 \\
\hline
\end{tabular}

*Eight men and eight women receiving fibrate treatment were excluded. tPercentages of patients with one, two, or three coronary arteries with $>50 \%$ stenosis. $n$, number; CAD, coronary artery disease. 
reduce the rates of acute coronary ischaemic events in individuals with dyslipidaemia by over $20 \%{ }^{4{ }^{5}}$ Recently, Flavell et al showed an association between the $\mathrm{C}$ allele of the PPAR $\alpha$ gene intron 7 polymorphism and increased risk of ischaemic heart disease in a prospective study. ${ }^{17}$ The results of our study provide further evidence of this association and indicate that this genotypic effect is greater in women than in men.

An association between the Leu/Leu genotype and higher prevalence of hypertension, particularly in women, was also observed in this study. It has been shown in animal experiments that PPAR $\alpha$ agonist fenofibrate can improve endothelium and also nitric oxide mediated vasodilation. ${ }^{31}$ Since the 162Leu isoform has a lower transcriptional activity than the 162Val isoform, ${ }^{19}$ it is possible that there is a decrease in vasodilation in persons with the Leu/Leu genotype, which may explain the association between the Leu/Leu genotype and hypertension.

In a recent study of healthy individuals, carriers of the 162Val allele were found to have lower body mass index values than 162Leu homozygotes, and this difference was more pronounced among women. ${ }^{15}$ In another study, the $162 \mathrm{Val}$ allele was associated with lower body mass in persons with type 2 diabetes but not in healthy individuals, patients attending lipid clinics, or morbidly obese patients who underwent gastric banding surgery. ${ }^{16}$ In the present study, no significant difference in body mass index was found between the genotype groups. The differing findings of these studies could be related to differences in the characteristics of the participants. Since coronary artery disease is caused by interactions between multiple environmental and genetic factors, it is likely that the genetic backgrounds and the exposures to environmental risk factors, such as high fat diets, of the subjects with coronary artery disease of our study were different from those of the subjects of the other two studies mentioned above. ${ }^{15}{ }^{16}$ These genetic and environmental factors might influence the genotypic effects of PPAR $\alpha$ on adiposity.

The Leul62Val and intron $7 \mathrm{G}>\mathrm{C}$ polymorphisms are in strong linkage disequilibrium, with the Val allele linked with the $\mathrm{C}$ allele. These two polymorphisms define four haplotypes, namely Leu-G, Leu-C, Val-G, and Val-C. None of these haplotypes was found to be more significantly associated with plasma triglyceride level or prevalence of hypertension than the Leul62Val polymorphism, and none of the haplotypes had a more significant association with myocardial infarction than the intron $7 \mathrm{G}>\mathrm{C}$ polymorphism, suggesting that the Leul62Val and intron $7 \mathrm{G}>\mathrm{C}$ polymorphisms do not have an additive effect on these traits and do not mark the effects of another genetic variant through linkage disequilibrium.

In summary, in this study of a large cohort of patients with coronary artery disease, we found that the PPAR $\alpha$ gene Leu162Val polymorphism was associated with plasma levels of triglyceride in a gender dependent manner and that, in the men, there was an interaction between this genetic polymorphism and statin treatment in determining triglyceride levels. We also detected an association between the Leul62Val polymorphism and prevalence of hypertension, and an association between the intron $7 \mathrm{G}>\mathrm{C}$ polymorphism and myocardial infarction, although the latter was not highly significant statistically. The subjects of this study were recruited from patients with coronary artery disease consecutively undergoing coronary angiography. In a manner consistent with the different susceptibilities to coronary artery disease of the two genders, men and women differed in some characteristics such as age, percentage of smokers, and family history of coronary artery disease. Thus, it is possible that men and women might be influenced by differing environmental and genetic factors. Nevertheless, the findings of this study are in agreement with the pleiotropic effects of PPAR $\alpha$ on lipid metabolism and the pathophysiology of the cardiovascular system, ${ }^{3}$ and indicate that the genotypic effects of PPAR $\alpha$ on men with coronary artery disease and women with coronary artery disease do differ. Gender specific effects of another gene involved in lipid metabolism, the apolipoprotein E gene, have been reported previously. ${ }^{32}$ The gender dependent effects of these genes might be a mechanism contributing to the differences in lipid levels and incidence of cardiovascular diseases between men and women.

\section{ACKNOWLEDGEMENTS}

Patient recruitment was undertaken by the Southampton Atherosclerosis Study (SAS) group (S Ye, I Simpson, I Day, W Bannister, L Day, and L Dunleavey), whose help we acknowledge with thanks.

\section{Authors' affiliations}

Q H Khan, Shu Ye, Human Genetics Division, School of Medicine, University of Southampton, UK

D E Pontefract, S lyengar, Wessex Cardiac Unit, Southampton General Hospital, UK

This work was supported by the British Heart Foundation (PG98/183, PG98/192, PG2001/105, PG02/053).

Correspondence to: $\operatorname{Dr} \mathrm{S}$ Ye, Human Genetics Division, Duthie Building (mp808), Southampton General Hospital, Southampton SO16 6YD, UK; Shu.Ye@soton.ac.uk

\section{REFERENCES}

1 Schoonjans K, Martin G, Staels B, Auwerx J. Peroxisome proliferatoractivated receptors, orphans with ligands and functions. Curr Opin Lipidol 1997:8:159-66.

2 Berger J, Moller DE. The mechanisms of action of PPARs. Annu Rev Med 2002;53:409-35

3 Barbier O, Torra IP, Duguay Y, Blanquart C, Fruchart JC, Glineur C, Staels B. Pleiotropic actions of peroxisome proliferator-activated receptors in lipid metabolism and atherosclerosis. Arterioscler Thromb Vasc Biol 2002;22:717-26.

4 Frick MH, Elo O, Haapa K, Heinonen OP, Heinsalmi P, Helo P, Huttunen JK, Kaitaniemi P, Koskinen P, Manninen V. Helsinki Heart Study: primaryprevention trial with gemfibrozil in middle-aged men with dyslipidemia. Safety of treatment, changes in risk factors, and incidence of coronary heart disease. N Engl J Med 1987;317:1237-45.

5 Rubins $\mathrm{HB}$, Robins SJ, Collins D, Fye CL, Anderson JW, Elam MB, Faas FH, Linares E, Schaefer EJ, Schectman G, Wilt TJ, Wittes J. Gemfibrozil for the secondary prevention of coronary heart disease in men with low levels of high density lipoprotein cholesterol. Veterans Affairs High-Density Lipoprotein Cholesterol Intervention Trial Study Group. N Engl J Med 1999;341:410-18.

6 Diouadi F, Weinheimer CJ, Saffitz JE, Pitchford C, Bastin J, Gonzalez FJ, Kelly DP. A gender-related defect in lipid metabolism and glucose homeostasis in peroxisome proliferator-activated receptor alpha-deficient mice. J Clin Invest 1998;102:1083-91.

7 Jalouli M, Carlsson L, Ameen C, Linden D, Liungberg A, Michalik L, Eden S, Wahli W, Oscarsson J. Sex difference in hepatic peroxisome proliferatoractivated receptor alpha expression: influence of pituitary and gonadal hormones. Endocrinology 2003;144:101-9.

8 Linden D, Alsterholm M, Wennbo H, Oscarsson J. PPAR alpha deficiency increases secretion and serum levels of apolipoprotein B-containing lipoproteins. J Lipid Res 2001;42:1831-40.

9 Tai ES, Bin AA, Zhang Q, Loh LM, Tan CE, Retnam L, Oakley ERM, Lim SK. Hepatic expression of PPARalpha, a molecular target of fibrates, is regulated during inflammation in a gender-specific manner. FEBS Lett 2003;546:237-40

10 Lewitt MS, Brismar K. Gender difference in the leptin response to feeding in peroxisome-proliferator-activated receptor-alpha knockout mice. Int J Obes Relat Metab Disord 2002;26:1296-1300.

11 Costet P, Legendre C, More J, Edgar A, Galtier P, Pineau T. Peroxisome proliferator-activated receptor alpha-isoform deficiency leads to progressive dyslipidemia with sexually dimorphic obesity and steatosis. J Biol Chem 1998;273:29577-85.

12 Nohammer C, Brunner F, Wolkart G, Staber PB, Steyrer E, Gonzalez FJ, Zechner R, Hoefler G. Myocardial dysfunction and male mortality in peroxisome proliferator-activated receptor alpha knockout mice overexpressing lipoprotein lipase in muscle. Lab Invest 2003;83:259-69.

13 Tai ES, Demissie S, Cupples LA, Corella D, Wilson PW, Schaefer EJ, Ordovas JM. Association between the PPARA L162V polymorphism and 
plasma lipid levels: the Framingham Offspring Study. Arterioscler Thromb Vasc Biol 2002;22:805-10.

14 Lacquemant C, Lepretre F, Pineda Torra I, Manraj M, Charpentier G, Ruiz J, Staels B, Froguel P. Mutation screening of the PPARalpha gene in type 2 diabetes associated with coronary heart disease. Diabetes Metab 2000;26:393-401.

15 Bosse Y, Despres JP, Bouchard C, Perusse L, Vohl MC. The peroxisome proliferator-activated receptor alpha L162V mutation is associated with reduced adiposity. Obes Res 2003;11:809-16.

16 Evans D, Aberle J, Wendt D, Wolf A, Beisiegel U, Mann WA. A polymorphism, L162V, in the peroxisome proliferator-activated receptor alpha (PPARalpha) gene is associated with lower body mass index in patients with non-insulin-dependent diabetes mellitus. J Mol Med 2001;79:198-204

17 Flavell DM, Jamshidi Y, Hawe E, Pineda Torra I, Taskinen MR, Frick MH, Nieminen MS, Kesaniemi YA, Pasternack A, Staels B, Miller G, Humphries SE Talmud PJ, Syvanne M. Peroxisome proliferator-activated receptor alpha gene variants influence progression of coronary atherosclerosis and risk of coronary artery disease. Circulation 2002;105:1440-5.

18 Vohl MC, Lepage P, Gaudet D, Brewer CG, Betard C, Perron P, Houde G, Cellier C, Faith JM, Despres JP, Morgan K, Hudson TJ. Molecular scanning of the human PPARa gene: association of the L162v mutation with hyperapobetalipoproteinemia. J Lipid Res 2000;41:945-52.

19 Flavell DM, Pineda Torra I, Jamshidi Y, Evans D, Diamond JR, Elkeles RS, Bujac SR, Miller G, Talmud PJ, Staels B, Humphries SE. Variation in the PPARalpha gene is associated with altered function in vitro and plasma lipid concentrations in Type II diabetic subjects. Diabetologia 2000;43:673-80.

20 Ye S, Dunleavey L, Bannister W, Day LB, Tapper W, Collins AR, Day IN, Simpson I. Independent effects of the $-219 \mathrm{G}>\mathrm{T}$ and epsilon 2/ epsilon 3/ epsilon 4 polymorphisms in the apolipoprotein $\mathrm{E}$ gene on coronary artery disease: the Southampton Atherosclerosis Study. Eur J Hum Genet 2003; 11:437-43.

21 Morgan AR, Zhang BP, Tapper W, Collins A, Ye S. Haplotypic analysis of the MMP-9 gene in relation to coronary artery disease. J Mol Med 2003:81:321-6.

22 Niu T, Qin ZS, Xu X, Liu JS. Bayesian haplotype inference for multiple linked single-nucleotide polymorphisms. Am J Hum Genet 2002;70:157-69.

23 Jamshidi Y, Flavell DM, Hawe E, MacCallum PK, Meade TW, Humphries SE. Genetic determinants of the response to bezafibrate treatment in the lower extremity arterial disease event reduction (LEADER) trial. Atherosclerosis 2002;163: 183-92.
24 Yamakawa-Kobayashi K, Ishiguro H, Arinami T, Miyazaki R, Hamaguchi H. A Val227Ala polymorphism in the peroxisome proliferator activated receptor alpha (PPARalpha) gene is associated with variations in serum lipid levels. J Med Genet 2002;39:189-91

25 Brisson D, Ledoux K, Bosse Y, St Pierre J, Julien P, Perron P, Hudson TJ, Vohl MC, Gaudet D. Effect of apolipoprotein E, peroxisome proliferatoractivated receptor alpha and lipoprotein lipase gene mutations on the ability of fenofibrate to improve lipid profiles and reach clinical guideline targets among hypertriglyceridemic patients. Pharmacogenetics 2002; 12:313-20

26 Bosse Y, Pascot A, Dumont M, Brochu M, Prud'homme D, Bergeron J, Despres JP, Vohl MC. Influences of the PPAR alpha-L162V polymorphism on plasma HDL(2)-cholesterol response of abdominally obese men treated with gemfibrozil. Genet Med 2002;4:31 1-15.

27 Martin G, Duez H, Blanquart C, Berezowski V, Poulain P, Fruchart JC, NajibFruchart J, Glineur C, Staels B. Statin-induced inhibition of the Rho-signaling pathway activates PPARalpha and induces HDL apoA-I. J Clin Invest $2001 ; 107: 1423-32$

28 Inoue I, Goto S, Mizotani K, Awata T, Mastunaga T, Kawai S, Nakajima T, Hokari S, Komoda T, Katayama S. Lipophilic HMG-CoA reductase inhibito has an anti-inflammatory effect: reduction of MRNA levels for interleukin1 beta, interleukin-6, cyclooxygenase-2, and p22phox by regulation of peroxisome proliferator-activated receptor alpha (PPARalpha) in primary endothelial cells. Life Sci 2000;67:863-76.

29 Inoue I, Itoh F, Aoyagi S, Tazawa S, Kusama H, Akahane M, Mastunaga T, Hayashi K, Awata T, Komoda T, Katayama S. Fibrate and statin synergistically increase the transcriptional activities of PPARalpha/RXRalpha and decrease the transactivation of NFkappaB. Biochem Biophys Res Commun 2002;290:131-9.

30 Francis GA, Annicotte JS, Auwerx J. PPAR \{alpha\} effects on the heart and other vascular tissues. Am J Physiol Heart Circ Physiol 2003;285(1):H1-9.

31 Tabernero A, Schoonjans K, Jesel L, Carpusca I, Auwerx J,

Andriantsitohaina R. Activation of the peroxisome proliferator-activated receptor alpha protects against myocardial ischaemic injury and improves endothelial vasodilatation. BMC Pharmacology 2002;2:10.

32 Reilly SL, Ferrell RE, Sing CF. The gender-specific apolipoprotein E genotype influence on the distribution of plasma lipids and apolipoproteins in the population of Rochester, MN. III. Correlations and covariances. Am J Hum Genet 1994;55:1001-18. 